\title{
Geochemistry and tectonic implications of mafic sills in Lower Paleozoic formations of southwestern Nova Scotia
}

\author{
Sandra M. Barr, Eibhlin M. Doyle and Linda S. Trapasso \\ Department of Geology, Acadia University, Wolfville, N.S. BOP 1XO
}

\begin{abstract}
Mafic sills are abundant in the early Palaeozoic Halifax, White Rock and Torbrook Formations exposed along the northwestern margin of the South Mountain batholith in southwestern Nova Scotia. Field observations, petrography, and geochemistry indicate that the sills are of at least two ages. Sills of the older type are restricted to the Halffax Formation, and were reglonally metamorphosed and folded together with their host rocks during the Acadian Orogeny. These sills are generally $1 \mathrm{~m}$ or less in width and are inferred to be approximately penecontemporaneous with their host rocks (Ordovictan). Sills of the younger type intruded all three formations, including the EarIy Devonian Torbrook Formation, but apparently predated the South Mountain batholith, and hence at least in part are early to middle Devonian in age. They are generally larger than the older sills and concordant with Acadian structural trends but not demonstrably folded. Sills of both types are essentially basaltic in composition, but are extensively altered. Wide ranges in chemical composition largely reflect this alteration which partly obscures chemlcal differences between the two types. Both are tholeitic transitional to alkalic, but the older sills appear to have more alkalic tendencies. Both types were emplaced in a continental within-plate environment, thus placing constraints on tectonic models for southwestern Nova Scotia during the early Palaeozolc.
\end{abstract}

\begin{abstract}
Les filons-couches abondent dans les formations de Halifax, de White Rock et de Torbrook (Paléozoĩque inférleur) le long de la bordure nord-ouest du batholite South Mountain au sudouest de la Nouvelle-Ecosse. Les observattons de terrain, la pétrographie et la géochimle indiquent que les filons-couches se partagent en au moins deux groupes chronologiques. Les plus anciens filons-couches se retrouvent seulement dans la formation de Halffax et, avec la roche hôte, ont subi le metamorphisme régional et le plissement causé par l'orogénie Acadienne. Ces filons-couches mesurent généralement $1 \mathrm{~m}$ ou moins de largeur et on croit qu'ils ont été mis en place à peu près en même temps que la roche hôte (Ordovicten). Les filons-couches plus jeunes recoupent les trois formations, y inclus la formation de Torbrook (Dévonien), mais comme ils semblent antécédents au batholite. South Mountain ils dateraient donc, au moins en partie, du début au milieu du Dévonien. Ils sont généralement de plus grande dimension que les anciens filons-couches et s'accordent avec les lignes structurales Acadiennes sans toutefois paraître plissés. Les deux types de filons-couches sont essentiellement de compositłon basaltique mais sont profondément modifiés. La grande variation des compositions chimiques réflète cette modification qui obscurcit les différences chimiques entre les deux types. Les deux types de filons-couches furent mis en piace au sein d'une plaque continentale ce qui. impose des limites aux modèles tectoniques du sud-ouest de la Nouvelle-Ecosse pour le PaléozoĨque inférieur.
\end{abstract}

[Traduit par le journal].

\section{INTRODUCTION}

Lower Palaeozoic rocks, predominantly sedimentary in origin, are exposed along the northwestern margin of the South Mountain batholith in southwestern Nova Scotia (Fig. 1). In the Bear River and Nictaux-Torbrook areas, these rocks have been the focus of recent projects at Acadia University involving primarily mapping and structural studies (Doyle 1979; Trapasso 1979). This work has shown that mafic sills are abundant in the lower Palaeozoic rocks of both these areas. Although the Palaeozoic rocks in the Wolfville-Kentville area have

MARITIME SEDIMENTS AND ATLANTIC GEOLOGY $19,73-87$ (1983) not yet been studied in the same detail, numerous sills are also known to be common in this area (personal observations). Sills in all three areas were noted by earlier workers (Loring 1956, Smitheringale 1960, 1973; Taylor 1969), but they are much more abundant than generally documented. Only limited descriptions of their petrology have previously been presented (e.g. Riley 1964, Smitheringale 1973, White 1978).

Intrusions in such abundance suggest an igneous event or events significant in the geological history of southwestern Nova Scotia. They may be especially important in view of the uncer- 


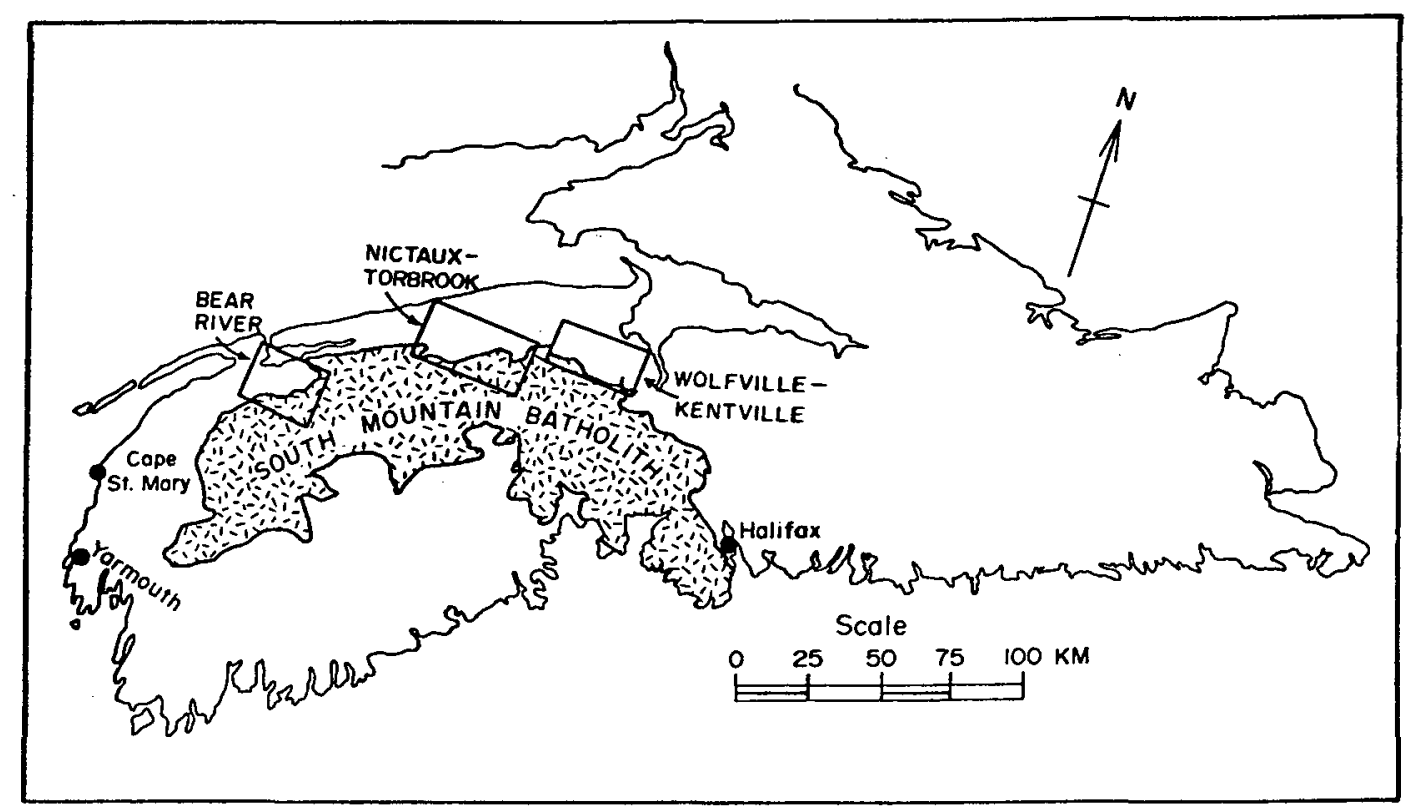

Fig. 1 - Outline map of part of Nova Scotia showing the locations of the Bear River, Nictaux-Torbrook, and Wolfville-Kentville study areas.

tainties in Early Palaeozoic evolution of the Meguma Zone (Schenk 1971, Keppie 1982, Williams 1978, Williams and Hatcher 1982). The purpose of this paper is to describe the field relations and petrology of the intrusions, to determine their chemical affinities, and to speculate on their age(s) and tectonic implications.

\section{GENERAL GEOLOGY}

Sills have been mapped in the Halifax, White Rock and Torbrook Formations in the three study areas (Figs. 2,3,4).

The Halifax Formation of Tremadocian age is the most widespread lower Palaeozoic unit in these areas (Crosby 1962, Smitheringale 1973, Doyle 1979). It consists predominantly of slate, and has been interpreted to have been deposited in a deep-sea fan environment (Schenk 1971, Harris and Schenk 1976, Keppie 1977) or, more recently, on a submarine plateau (Keppie 1982).

The upper Ordovician to Silurian White Rock Formation has been generally interpreted to disconformably overlie the Halifax Formation (Smitheringale 1973, Keppie and Dostal 1980), although local angular unconformities (Taylor 1969) or thrust faulted contacts may also exist (Keppie and Dostal 1980). In the Wolfville-Kentville area (Fig. 4), the White Rock Formation consists dominantly of clean quartzite with minor interbanded slate (Crosby 1962). In the Nictaux-Torbrook area (Fig. 3), felsic tuff and basalt occur near the base of the White Rock Formation, underlain by thin calcareous siltstones and tuffaceous sedimentary rocks (a11 metamorphosed) (Smitheringale 1973, Lane 1976). Above the volcanic rocks are shallow marine sedimentary units, including quartzite and slate. In the Bear River area (Fig. 2) the volcanic rocks are again absent, and the White Rock Formation consists of a shallow marine sequence of metasiltstone, metagreywacke, and quartzite (Smitheringale 1973, Doyle 1979). However, farther to the southwest in the Cape St. Mary and Yarmouth areas (Fig. 1), volcanic rocks form the major part of the White Rock Formation (Taylor 1969, Sarkar 1978, Keppie and Dostal 1980).

In the Bear River area (Fig. 2) and most of the Nictaux Torbrook area (Fig. 3 ), the White Rock Formation is conformably overlain by the Lower Devonian Torbrook Formation which includes fos- 
siliferous siltstone, shale and quartz arenite (Smitheringale 1973). However in part of the Nictaux-Torbrook area and in the Wolfville-Kentville area (Fig. 4) the White Rock Formation is overlain by slates of the Upper Silurian Kentville Formation in'which no sills have as yet been recognized. In the Wolfville-Kentville area, the Kentville Formation is overlain by the New Canaan Formation, also Late Silurian in age, which consists of pyroclastic rocks and/or metabasalts with interbedded shallow marine metasedimentary rocks and poorly exposed mafic intrusions (Crosby 1963, Clarke 1977). The latter may be related to the sills of this study.

All of these rock units were deformed into major northeast-trending subhorizontal folds with related minor structures (Doyle 1979, Trapasso 1979) during the Acadian Orogeny and, with the apparent exception of the Torbrook Formation (Doyle 1979), underwent greenschist facies regional metamorphism (Smitheringale 1973, Lane 1976). They were subsequently intruded and local- 1y contact metamorphosed by the DevonoCarboniferous South Mountain batholith and related granitoid intrusions.

\section{SILLS}

\section{Field Relations}

On the basis of field observations, the sills are divided into two groups referred to as Type I and Type II. Type I sills were observed only in the Halifax Formation. They are the dominant type in the Bear River area (195 out of 230 mapped outcrops), and are a1so common in the Wolfville-Kentville area (15 out of 21 known sill outcrops), but have been recognized only at the northeastern end of the Nictaux-Torbrook area. (Fig. 4). These sills are generally small (less than $2 \mathrm{~m}$ in width), weather light brown in colour, and are easily mistaken for metasiltstone beds in the field, although close inspection will reveal narrow chilled margins, and relict igneous textures are usually apparent in thin section. They are also commonly vesicular (in contrast to the Type II sills which

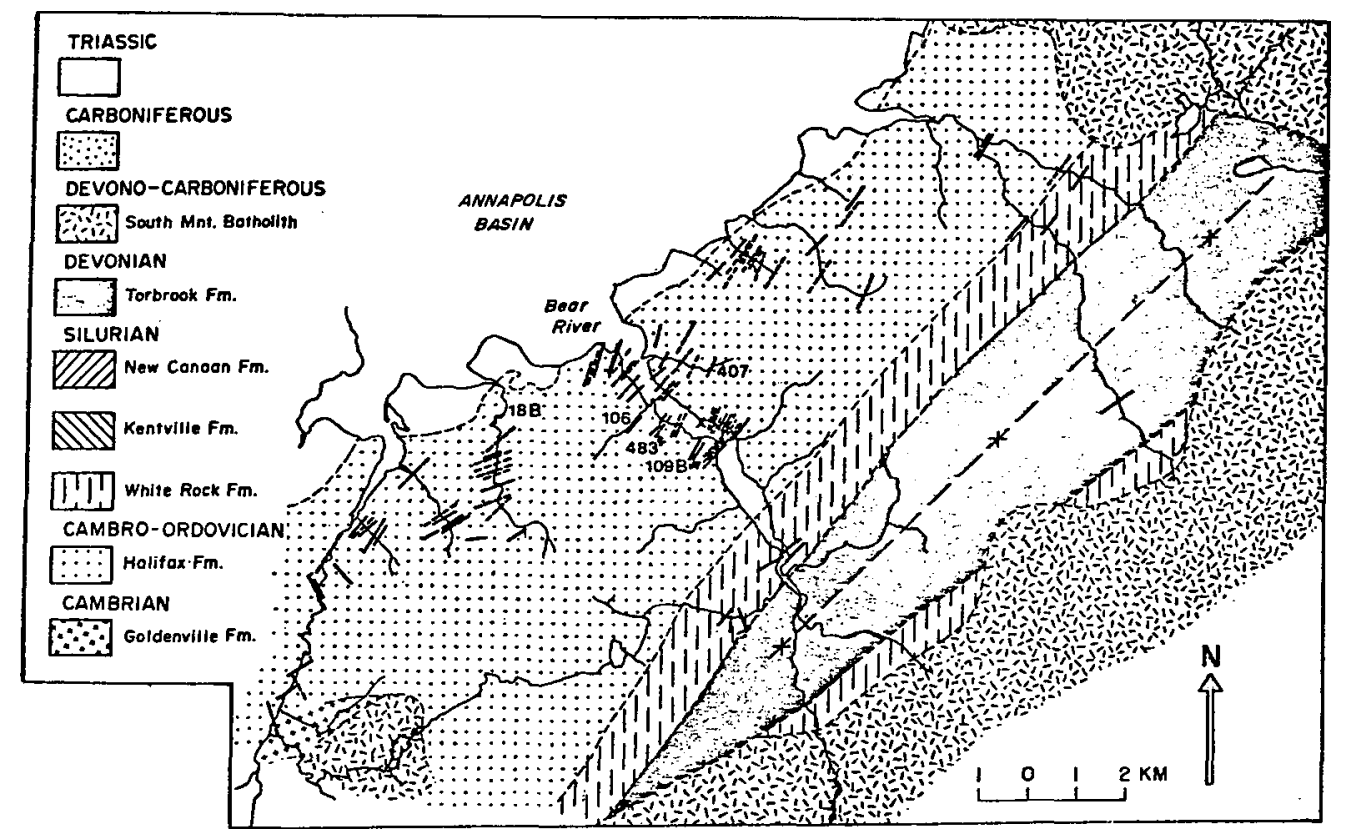

Fig. 2 - Simplified geological map of the Bear River area (modified from Doyle 1979). Dashed and solid straight lines indicate approximate locations and orientations of Type I and Type II sills, respectively. Numbered sills are those containing analyzed relict clinopyroxenes (Table 2) or otherwise referred to in the text. 


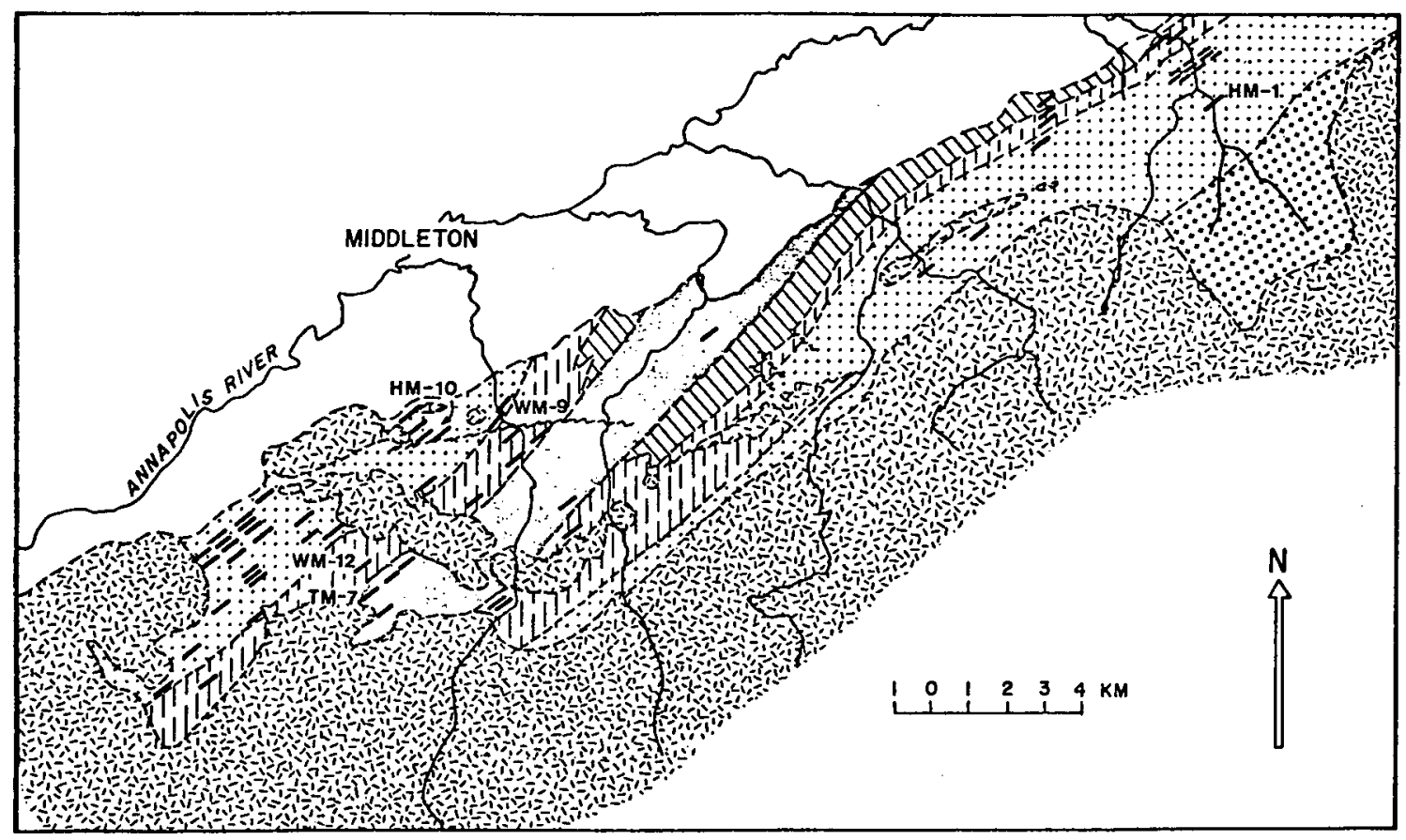

Fig. 3 - Simplified geological map of the Nictaux-Torbrook area (modified from Trapasso 1979). Dashed and solid straight lines indicate approximate locations and orientations of Type I and Type II sills, respectively. Numbered sills are those containing analyzed relict clinopyroxenes (Table 2).

rarely, if ever, display vesicular texture) and locally show multiple intrusion one into another. At one 10cality on Bear River (Fig. 2, Locality $X)$, several vesicular sills display irregular contacts with contorted sedimentary laminae of the host Halifax Formation (Fig. 5). These relationships may be the result of thixotropic deformation during sill emplacement. At many localities, Type I sills have been folded together with their host rocks into complete mesoscopic folds, as illustrated by Smitheringale (1973) in a frontispiece. They locally display foliation of variable intensity parallel to that in the enclosing slates. The Type I sills are in part equivalent to the "spilitic" sills of Smitheringale (1973), although the large "spilitic" sills which he described were not recognized during the present study. They probably belong to Type II as here defined.

The Type II sills were found in the Halifax, White Rock, and Torbrook Formations and are the dominant type in the Nictaux-Torbrook area. They are generally larger and much more obvious in the field than the Type I sills. They are generally between $I$ and $40 \mathrm{~m}$ but typically about $5 \mathrm{~m}$ in width. They are dark grey to green in colour with medium-grained "diabasic" interiors and finer-grained marginal zones. Foliation of variable intensity is developed near their margins, conformable with that in the host rocks. The Type II sills were nowhere observed to be folded, and appear to have been emplaced parallel to foliation rather than bedding. However, the term "sill" is retained because they are generally concordant with regional trends.

\section{Petrography}

The Type I sills are fine-grained and highly altered. Relict saussuritized plagioclase laths are generally recognizable, in some samples showing flow alignment. Clinopyroxene is rarely present. Magnetite and/or ilmenite vary in abundance and probably include both primary and secondary crystals. Other 
secondary minerals are chlorite, sericite, epidote, albite, calcite, leucoxene, pyrite, and hematite. Some samples contain a brownish groundmass of fine-grained secondary minerals which may have originally been glass. Vague outlines of what were probably. phenocrysts of a mafic mineral (pyroxene?) are present in some sills.

The Type II sills are generally less altered than those of Type I. Major minerals are plagioclase (andesinelabradorite) and augite with accessory opaques and apatite in ophitic, subophitic, or, more rarely, intergranular texture. Flow alignment of feldspars and altered phenocrysts are recognizable in some samples. The plagioclase is partially saussuritized, but composition can usually be determined from relict twinning. The augite is partially or, in some samples, completely pseudomorphed by chlorite and other secondary minerals. Green amphibole is the dominant mafic mineral in some sills, apparently replacing pyroxene. Carbonate is also a common secondary mineral, as well as epidote, quartz, pyrite and leucoxene. Flakes of biotite occur in some sills, apparently the result of local contact metamorphism from granitoid intrusions.

The essentially "spilitic" mineralogy of the Type I sills suggests that "ocean-floor type" metamorphism and/or low-grade regional metamorphism altered these rocks. In contrast, mineralogy of the Type II sills, especially the preservation of calcic plagioclase compositions, is more consistent with deuteric or hydrothermal alteration. This is also supported by the fact that Type II sills in the Torbrook Formation which is essentially unmetamorphosed (or at least sub-greenschist facies) are also extensively altered, although with less well crystallized amphibole.

\section{Chemistry}

Methods

Major element analyses were done at Acadia University by atomic absorption spectrometry ( $\mathrm{Si}, \mathrm{Ti}, \mathrm{Al}, \mathrm{Fe}, \mathrm{Mn}, \mathrm{Mg}$, $\mathrm{Ca})$ and flame photometry $(\mathrm{Na}, \mathrm{K})$, using a method modified from Buckley and

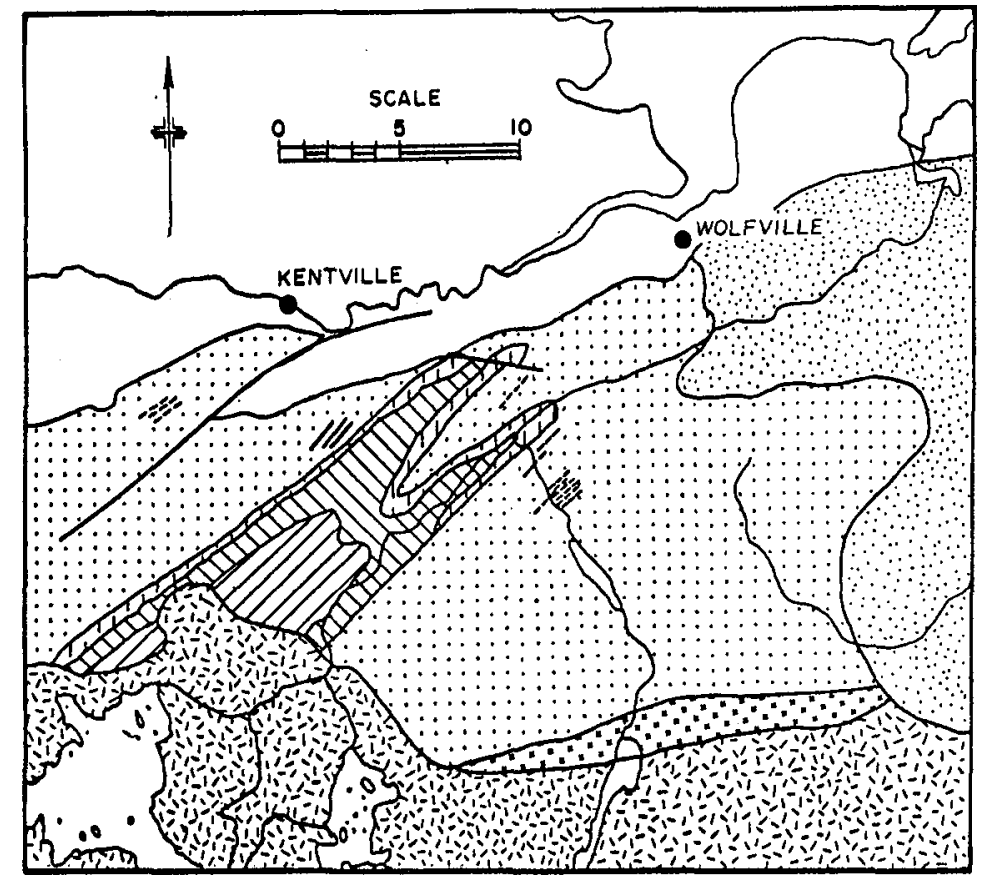

Fig. 4 - Simplified geological map of the Wolfville-Kentville area (modified from Keppie 1979). Dashed and solid lines indicate approximate locations and orientations of Type I and Type II sills, respectively. 


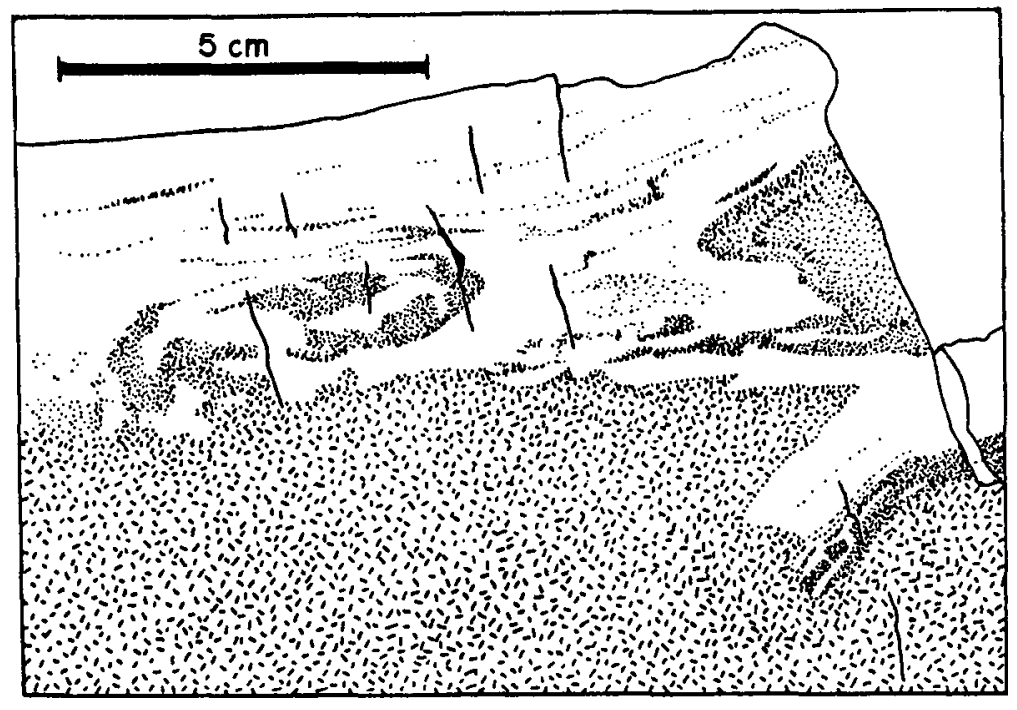

Fig. 5 - Line drawing from a photograph of an outcrop displaying deformation of pelitic (unstippled) and psammitic (fine stipple) laminae adjacent to a Type I sill (random slashes). Locality X, Fig. 2.

Cranston (1971) and described by Doyle (1979). Loss on ignition was determined as percentage weight loss after heating for 1 hour at $1000^{\circ} \mathrm{C}$. Phosphorous was determined by colourimetry at Dalhousie University. Trace elements were analyzed at St. Mary's University ( $\mathrm{Ba}, \mathrm{La}, \mathrm{Ce}, \mathrm{Rb}, \mathrm{Sr}, \mathrm{Nb}, \mathrm{Zr}$ ) and Memorial University $(\mathrm{Nb}, \mathrm{Y}, \mathrm{Zr})$ by $\mathrm{X}$-ray fluorescence and at CLIM Laboratories, Technical University of Nova Scotia $(\mathrm{Nb}, \mathrm{Y}, \mathrm{Zr})$ by quantitative spectrographic analysis. Major elements in all samples, and trace elements in most, were analyzed at least in duplicate and the results used are general1y the average of the determinations. Individual analyses and locations of the samples are available in the Open File Library of the Nova Scotia Department of Mines and Energy.

\section{Alteration}

As to be expected in variably altered rocks, loss on ignition values are generally high (up to $12 \%$ ) especially in the Type I sills. In order to compare samples with varied but generally large losses on ignition, major element analyses were recalculated to total $100 \%$, volatile-free, and these data are used on diagrams involving major elements.
Although 10 samples from the Wolfville-Kentville area, 20 from the Nictaux-Torbrook area, and 45 from the Bear River area were analyzed, erratic scatter in the data indicated that many are too altered to give reliable results. In order to identify those sam. ples which might yield the most reliable data, two established chemical screens were applied: (i) $\mathrm{Na}_{2} \mathrm{O}$ and $\mathrm{K}_{2} \mathrm{O}$ values such as to place the sample within or close to the "igneous spectrum" (Fig. 6) of Hughes (1972) and (ii) $\mathrm{CaO}+\mathrm{MgO}$ between 12 and $20 \%$ (Stillman and Williams 1978). Loss on ignition was not a practical criterion to use because values are high in all of the Type I sills and in many of the Type II sills. The means and standard deviations of analyses which fitted the above criteria are presented in Table 1 .

\section{Chemical Trends and Affinities}

Even the screened samples display wide chemical variation, as shown by the large standard deviations in Table 1. The scatter in the chemical data is illustrated by selected silicavariation diagrams (Fig. 7). In spite of their apparently more intense alteration, the Type I sills display no more, 


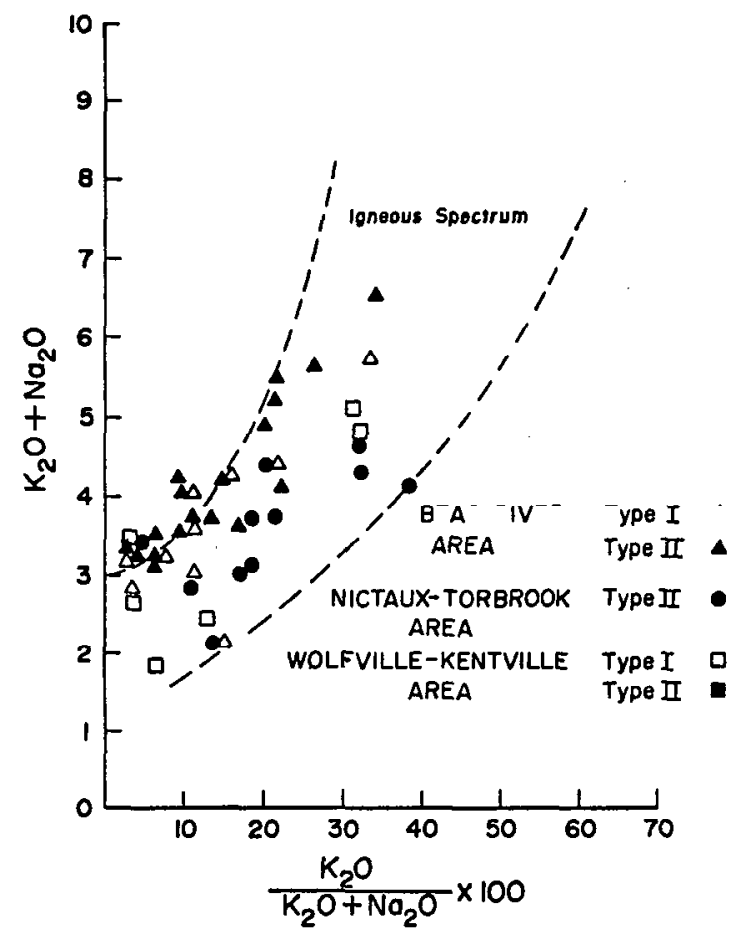

Fig. 6 - Analytical data for mafic sills of southwestern Nova Scotia plotted on the alkalies diagram of Hughes (1972). Igneous spectrum includes normal igneous rock compositions.

or even less, scatter than the Type II sills, suggesting that the differences between the two types are not due only to alteration. Because of the range of $\mathrm{SiO}_{2}$ contents and scatter in the data sets, the differences between the types are best revealed by trends on variation diagrams, especially those involving $\mathrm{SiO}_{2}, \mathrm{TiO}_{2}, \mathrm{P}_{2} \mathrm{O}_{5}$ and $\mathrm{Zr}$. In the Type II sills, $\mathrm{TiO}_{2}$ displays a weak negative correlation $(R=-0.37)$ with $\mathrm{SiO}_{2}$ whereas in Type I sills, $\mathrm{TiO}_{2}$ shows no correlation $(R=0.03)$ with $\mathrm{SiO}_{2}$ (Fig. 7a). $\quad \mathrm{P}_{2} \mathrm{O}_{5}$ has a weak positive correlation with $\mathrm{SiO}_{2}(\mathrm{R}=0.39)$ in Type I sills and a weak negative correlation $(R=-0.27)$ in Type II sil1s (Fig. 7e). Differences are further demonstrated by a plot of $\mathrm{TiO}_{2}$ against Zr (Fig. 8a) which shows different trends for Type I and Type II sills.

Both $\mathrm{TiO}_{2}$ and $\mathrm{P}_{2} \mathrm{O}_{5}$ have positive correlations with $\mathrm{Zr}$ in both types of sills (Fig. 8a, 8b). A positive correlation between $\mathrm{TiO}_{2}$ and $\mathrm{P}_{2} \mathrm{O}_{5}$ and $\mathrm{Zr}$ is typical of continental tholeiites. However a positive correlation between $\mathrm{TiO}_{2}$ and Zr has also been used to indicate that these elements have been affected by hydrothermal processes, during which both $\mathrm{Ti}$ and $\mathrm{Zr}$ have been diluted or
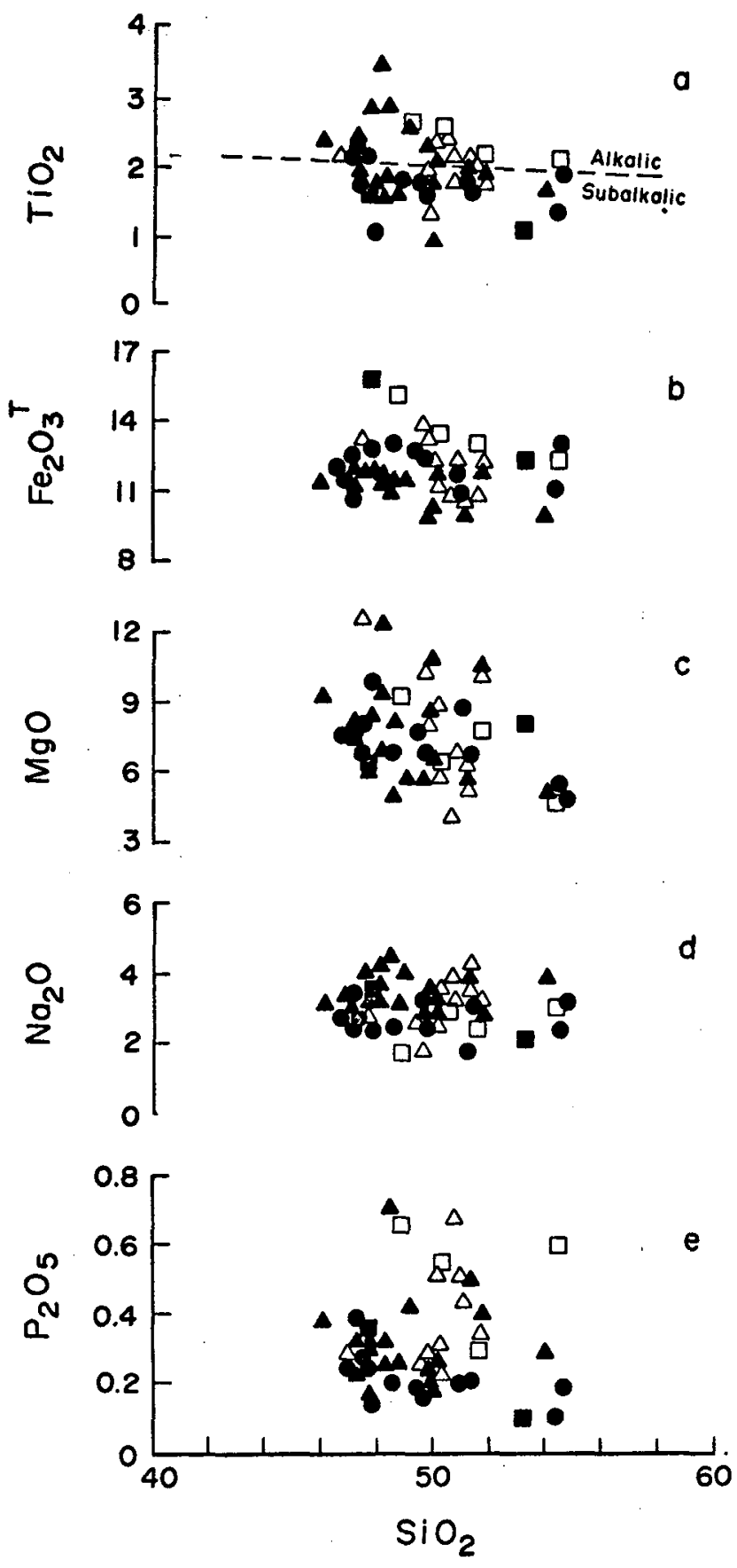

Fig. 7 - Silica variation diagram for analyses of mafic sills from the Bear River, Nictaux-Torbrook, and WolfvilleKentville areas. Symbols as in Fig. 6. Alkalic-tholeitic dividing line in the $\mathrm{TiO}_{2}$ diagram is from Whitehead and Goodfellow (1978). 
Table 1

MEANS AND STANDARD DEVIATIONS OF ORIGINAL ANALYSES* AND RECALCULATED ANALYSES (VOLATILE-FREE)

FOR SELECTED SILL SAMPLES FROM THE BEAR RIVER, NICTAUX-TORBROOK, AND WOLFVILLE-KENTVILLE

AREA, AS DESCRIBED IN THE TEXT

\begin{tabular}{|c|c|c|c|c|c|c|c|c|c|c|c|c|c|c|c|}
\hline \multirow[b]{3}{*}{8} & \multicolumn{6}{|c|}{ BEAR RIVER AREA } & \multicolumn{3}{|c|}{ NICTAUX-TORBROOK } & \multicolumn{6}{|c|}{ WOLFVILLE-KENTVILLE AREA } \\
\hline & \multicolumn{3}{|c|}{ Type I $(n=10)$} & \multicolumn{3}{|c|}{ Type II $(n=18)$} & \multicolumn{3}{|c|}{ Type II $(n=12)$} & \multicolumn{3}{|c|}{ Type I $(n=4)$} & \multicolumn{3}{|c|}{ Type II $(n=2)$} \\
\hline & \multicolumn{2}{|c|}{ Original } & \multirow[b]{2}{*}{$\begin{array}{c}\text { Recalc } \\
50.2 \\
2.0 \\
16.0 \\
12.1 \\
8.0 \\
0.18 \\
7.8 \\
3.0 \\
0.5 \\
0.37\end{array}$} & \multicolumn{2}{|c|}{ original } & \multirow[b]{2}{*}{$\begin{array}{c}\text { Recalc } \\
49.1 \\
2.1 \\
16.1 \\
11.6 \\
7.4 \\
0.18 \\
8.9 \\
3.5 \\
0.7 \\
0.33\end{array}$} & \multicolumn{2}{|c|}{ Original } & \multirow[b]{2}{*}{$\begin{array}{c}\text { Recalc } \\
49.8 \\
1.7 \\
15.8 \\
12.4 \\
7.2 \\
0.23 \\
9.2 \\
2.8 \\
0.8 \\
0.24\end{array}$} & \multicolumn{2}{|c|}{ original } & \multirow[b]{2}{*}{$\begin{array}{c}\text { Recalc } \\
51.3 \\
2.4 \\
14.6 \\
13.3 \\
6.9 \\
0.20 \\
7.2 \\
2.7 \\
0.8 \\
0.5\end{array}$} & \multicolumn{2}{|c|}{ Original } & \multirow[b]{2}{*}{$\begin{array}{c}\text { Recalc } \\
50.1 \\
1.4 \\
15.4 \\
13.5 \\
7.1 \\
0.17 \\
9.2 \\
2.7 \\
0.21 \\
0.20\end{array}$} \\
\hline $\begin{array}{l}\mathrm{SiO}_{2} \\
\mathrm{TiO}_{2} \\
\mathrm{Al}_{2} \mathrm{O}_{3} \\
\mathrm{Fe}_{2} \mathrm{O}_{3} \\
\mathrm{MgO} \\
\mathrm{MnO} \\
\mathrm{CaO} \\
\mathrm{Na}_{2} \mathrm{O} \\
\mathrm{K}_{2} \mathrm{O} \\
\mathrm{P}_{2} \mathrm{O}_{5} \\
\mathrm{LOI}\end{array}$ & $\begin{array}{l}46.4 \pm \\
1.8 \\
14.8 \\
11.0 \\
7.4 \\
0.16 \\
7.1 \\
2.7 \\
0.5 \\
0.35 \\
7.6\end{array}$ & $\begin{array}{l}2.7 \\
0.3 \\
1.5 \\
1.1 \\
2.1 \\
0.01 \\
0.8 \\
0.6 \\
0.5 \\
0.14 \\
3.2\end{array}$ & & $\begin{array}{c}47.2 \\
2.0 \\
15.3 \\
11.1 \\
7.2 \\
0.17 \\
8.3 \\
3.4 \\
0.7 \\
0.33 \\
4.8\end{array}$ & $\begin{array}{l} \pm 2.9 \\
0.6 \\
1.1 \\
0.7 \\
1.9 \\
0.13 \\
1.6 \\
0.5 \\
0.5 \\
0.13 \\
3.5\end{array}$ & & $\begin{array}{c}49.4 \pm \\
1.7 \\
15.6 \\
12.3 \\
7.1 \\
0.22 \\
9.1 \\
2.8 \\
0.8 \\
0.23 \\
1.3\end{array}$ & $\begin{array}{l} \pm 2.5 \\
0.3 \\
1.2 \\
0.7 \\
1.4 \\
0.05 \\
1.1 \\
0.5 \\
0.5 \\
0.07 \\
0.9\end{array}$ & & $\begin{array}{c}48.1 \pm \\
2.2 \\
13.7 \\
12.5 \\
6.5 \\
0.17 \\
6.8 \\
2.6 \\
0.8 \\
0.5 \\
6.3\end{array}$ & $\begin{array}{l}3.0 \\
0.2 \\
0.9 \\
0.9 \\
1.4 \\
0.06 \\
1.7 \\
0.7 \\
0.8 \\
0.1 \\
2.1\end{array}$ & & $\begin{array}{c}47.1 \pm \\
1.3 \\
14.4 \\
12.6 \\
6.4 \\
0.16 \\
8.7 \\
2.5 \\
0.2 \\
0.2 \\
5.6\end{array}$ & $\begin{array}{l}3.9 \\
0.4 \\
0.1 \\
1.1 \\
0.9 \\
0.03 \\
0.2 \\
0.7 \\
0.1 \\
0.1 \\
2.9\end{array}$ & \\
\hline \multicolumn{16}{|l|}{ ppm } \\
\hline $\begin{array}{l}\mathrm{Ba} \\
\mathrm{Rb} \\
\mathrm{Sr} \\
\mathrm{Nb} \\
\mathrm{Y} \\
\mathrm{Zr} \\
\mathrm{La} \\
\mathrm{Ce}\end{array}$ & $\begin{array}{r}341 \pm \\
24 \\
472 \\
20 \\
33 \\
182 \\
- \\
-\end{array}$ & $\begin{array}{r}230^{2} \\
15^{7} \\
191^{7} \\
6 \\
12 \\
35\end{array}$ & & $\begin{array}{r}566 \\
24 \\
553 \\
18 \\
30 \\
169 \\
- \\
-\end{array}$ & $\begin{array}{c}538^{3} \\
15^{14} \\
271^{14} \\
6 \\
7 \\
46\end{array}$ & & $\begin{array}{r}242 \pm \\
34 \\
474 \\
15 \\
27 \\
138 \\
16 \\
27\end{array}$ & $\begin{array}{c}160^{9} \\
31 \\
157 \\
6 \\
7 \\
39 \\
5^{9} \\
11^{9}\end{array}$ & & $\begin{array}{c}153^{1} \\
21 \\
673 \\
26^{3} \\
29^{3} \\
226 \\
- \\
-\end{array}$ & $\begin{array}{r}8 \\
141 \\
4 \\
10 \\
49\end{array}$ & & $\begin{array}{c}188^{1} \\
11 \pm \\
468 \\
10 \\
20 \\
116 \\
- \\
-\end{array}$ & $\begin{array}{c}4 \\
86 \\
3.5 \\
1 \\
43\end{array}$ & \\
\hline
\end{tabular}

* Superscript indicates number of analyses where it is less than the total cited above

* Total $\mathrm{Fe}$ as $\mathrm{Fe}_{2} \mathrm{O}_{3}$ 

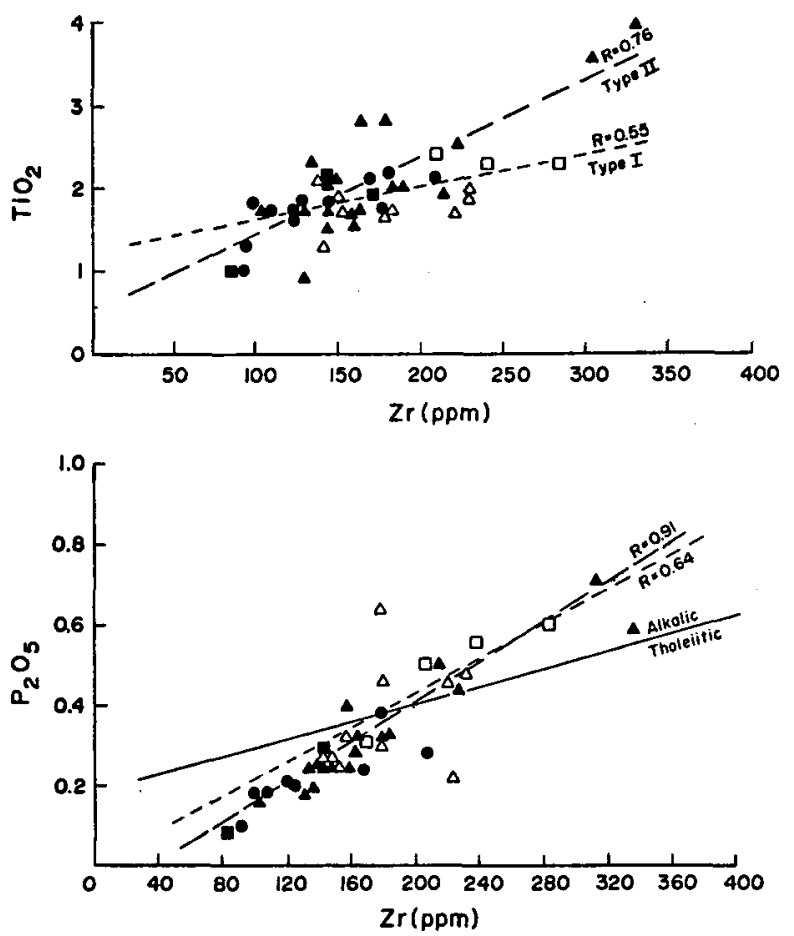

Fig. 8 - Plots of $\mathrm{TiO}_{2}$ (a) and $\mathrm{P}_{2} \mathrm{O}_{5}$ (b) against $\mathrm{Zr}$ for mafic sills from the Bear River, Nictaux-Torbrook, and Wolfville-Kentville areas. Symbols as in Fig. 6. Correlation coefficients for linear regression lines through Type I and Type II sill data are shown. Alkalic-tholeitic dividing line is after Floyd and Winchester (1975).

concentrated as a result of the mobility of other elements (Finlow-Bates and Strumpf1 1981).

On the basis of $\mathrm{TiO}_{2}$ and $\mathrm{P}_{2} \mathrm{O}_{5}$, both Type I and Type II sills are generally tholeiitic transitional to alkalic, with the Type I sills tending to be more alkalic (Fig. 7a, 8a). Similar affinities are suggested by various other diagrams, where many samples plot close to boundaries between subalkalic and alkalic fields (Fig. 9) or in areas of overlap between tholeiitic and alkalic fields (Figs. 10a, 10b, 11). Although considerable overlap of the two types occurs, the Type I sills tend to plot closer to the alkalic fields on these diagrams.

Both types of sills were apparently formed in a "within-plate" continental tectonic setting (Fig. 10a, 10b, 11, 12) although there is considerable spread, particularly into ocean-floor tholeiite fields. On Figure 12, the Type I sills tend to group slightly separate from the Type II sills, closer to the $\mathrm{Zr}$ apex.

Using La and Ce data, available only for Type II sills of the Nictaux-Torbrook area (Table 1), an additional indication of continental tholeiitic affinities is obtained, but again with some alkalic tendencies (Fig. 13).

\section{Pyroxene Compositions}

Relict clinopyroxene grains from one Type I sill and seven Type II sills were analyzed using the Cambridge Microscan 5 electron microprobe with Ortec energy dispersive system at Dalhousie University. Analyzed grains are of salite or augite composition (Table 1). Using the criteria of Nisbet and Pearce (1977), these analyses plot in fields for ocean-floor, within-plate tholeiitic, or within-plate alkalic basalts, with the exception of sample WM-9 which is clearly of within-plate tholeiite affinity (Fig. 14).

AGE(S) OF THE SILLS

Attempts to date the sills by the $\mathrm{K}-\mathrm{Ar}$ method were unsuccessful because of their degree of alteration. Preliminary whole-rock ages of 322 and $223 \mathrm{Ma}$ (Hayatsu, pers. comm., 1982)

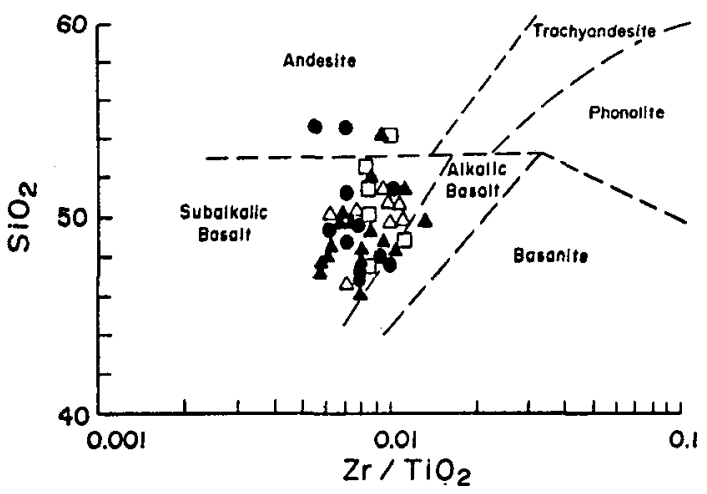

Fig. 9 - Plot of $\mathrm{SiO}_{2}$ against $\mathrm{Zr} / \mathrm{TiO}_{2}$ for mafic sills of the Bear River, Nictaux-Torbrook, and Wolfville-Kentville areas. Symbols as in Fig. 6. Fields are from Winchester and Floyd (1977). 
Table 2

MEANS AND STANDARD DEVIATIONS OF CLINOPYROXENE ANALYSES* FROM THE BEAR RIVER AND NICTAUX-TORBROOK AREAS**

\begin{tabular}{|c|c|c|c|c|c|c|c|c|}
\hline & \multicolumn{3}{|c|}{ BEAR RIVER } & \multicolumn{5}{|c|}{ NICTAUX-TORBROOK } \\
\hline & \multirow{2}{*}{$\begin{array}{c}\text { Type I } \\
\text { 109B }\end{array}$} & \multicolumn{2}{|c|}{ Type II } & \multicolumn{5}{|c|}{ Type II } \\
\hline & & 106 & 407 & HM-1 & $\mathrm{HM}-10$ & WM-9 & WM-12 & $T M-7$ \\
\hline $\begin{array}{l}\mathrm{SiO}_{2} \\
\mathrm{Al}_{2} \mathrm{O}_{3} \\
\mathrm{TiO}_{2} \\
\mathrm{FeO} \\
\mathrm{Cr}_{2} \mathrm{O}_{3} \\
\mathrm{MnO} \\
\mathrm{MgO} \\
\mathrm{CaO} \\
\mathrm{Na}_{2} \mathrm{O}\end{array}$ & 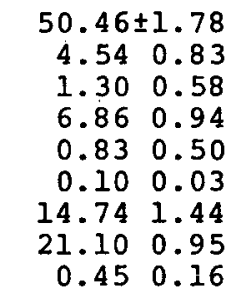 & 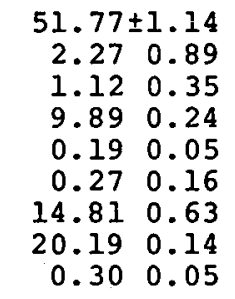 & 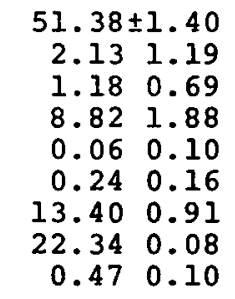 & 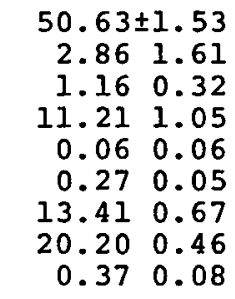 & 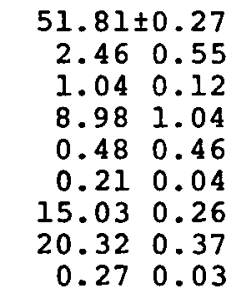 & 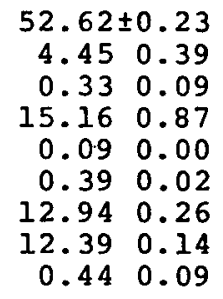 & 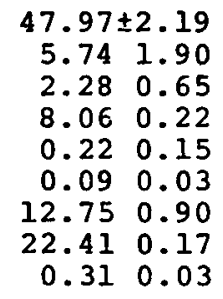 & $\begin{array}{rr}47.92 \pm 1.19 \\
5.58 & 0.89 \\
2.09 & 0.25 \\
7.54 & 0.23 \\
0.64 & 0.34 \\
0.11 & 0.01 \\
13.14 & 0.39 \\
22.34 & 0.31 \\
0.35 & 0.07\end{array}$ \\
\hline Total & 100.38 & 100.81 & 100.02 & 100.17 & 100.60 & 98.81 & 99.83 & 99.97 \\
\hline $\begin{array}{l}\mathrm{Si} \\
\mathrm{Al} i v i \\
\mathrm{Al} \\
\mathrm{Ti} \\
\mathrm{Fe} \\
\mathrm{Cr} \\
\mathrm{Mn} \\
\mathrm{Mg} \\
\mathrm{Ca} \\
\mathrm{Na}\end{array}$ & $\begin{array}{l}1.86 \\
0.14 \\
0.06 \\
0.04 \\
0.21 \\
0.02 \\
0.00 \\
0.81 \\
0.83 \\
0.03\end{array}$ & $\begin{array}{l}1.92 \\
0.08 \\
0.02 \\
0.03 \\
0.31 \\
0.01 \\
0.01 \\
0.82 \\
0.80 \\
0.02\end{array}$ & $\begin{array}{l}1.92 \\
0.08 \\
0.02 \\
0.03 \\
0.28 \\
0.00 \\
0.01 \\
0.75 \\
0.90 \\
0.03\end{array}$ & $\begin{array}{l}1.92 \\
0.08 \\
0.01 \\
0.03 \\
0.36 \\
0.00 \\
0.01 \\
0.76 \\
0.82 \\
0.03\end{array}$ & $\begin{array}{l}1.92 \\
0.08 \\
0.02 \\
0.03 \\
0.28 \\
0.01 \\
0.01 \\
0.83 \\
0.81 \\
0.02\end{array}$ & $\begin{array}{l}1.98 \\
0.02 \\
0.17 \\
0.01 \\
0.48 \\
0.00 \\
0.01 \\
0.72 \\
0.50 \\
0.03\end{array}$ & $\begin{array}{l}1.80 \\
0.20 \\
0.05 \\
0.06 \\
0.25 \\
0.01 \\
0.00 \\
0.71 \\
0.90 \\
0.02\end{array}$ & $\begin{array}{l}1.80 \\
0.21 \\
0.04 \\
0.06 \\
0.24 \\
0.02 \\
0.00 \\
0.75 \\
0.90 \\
0.03\end{array}$ \\
\hline
\end{tabular}

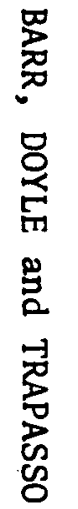

* Average of 3 grains in all samples except HM-10 where $n=4$

** Sample locations indicated on Figure 2 
from Type I sills $18 \mathrm{~B}$ and $483 \mathrm{~A}$ (Fig. 2) are obviously too young.

Many of the petrographic features of the Type I sills could be explained by their typically small size compared to the Type II sills (although the size ranges overlap between about 3 and $5 \mathrm{~m}$ ). However, the Type I sills appear to be chemically distinct from the Type II sills, and their local vesicularity and evidence of possible thixotropic deformation suggests that they may have been intruded at shallow depth. This implies that they may be similar in age to their Lower Ordovician host rocks.
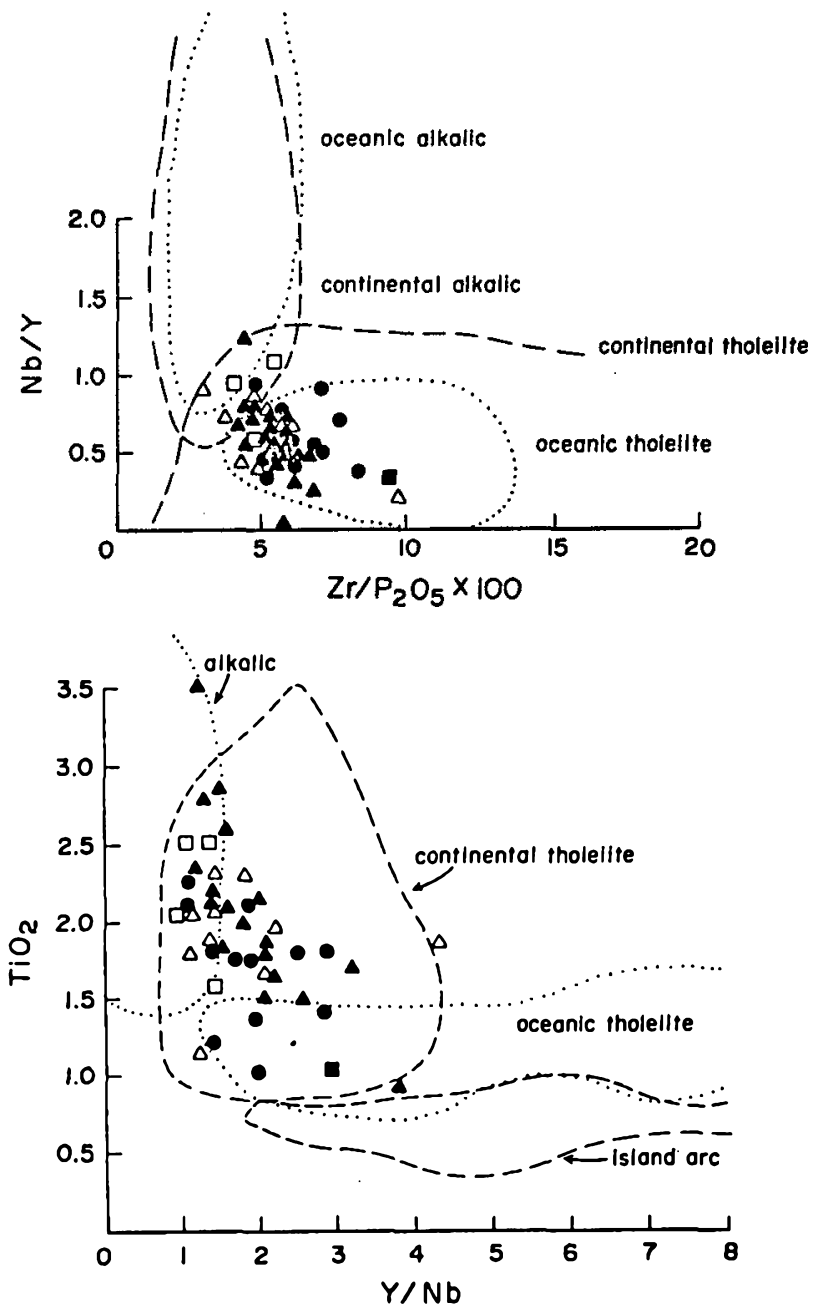

Fig. 10 - Plots of $\mathrm{Nb} / \mathrm{Y}$ against $\mathrm{Zr} / \mathrm{P}_{2} \mathrm{O}_{5}$ (a) and $\mathrm{TiO}_{2}$ against $\mathrm{Y} / \mathrm{Nb}$ (b) for mafic sills of the Bear River, Nictaux-Torbrook, and Wolfville-Kentville areas. Symbols as in Fig. 6. Fields are from Floyd and Winchester (1975).

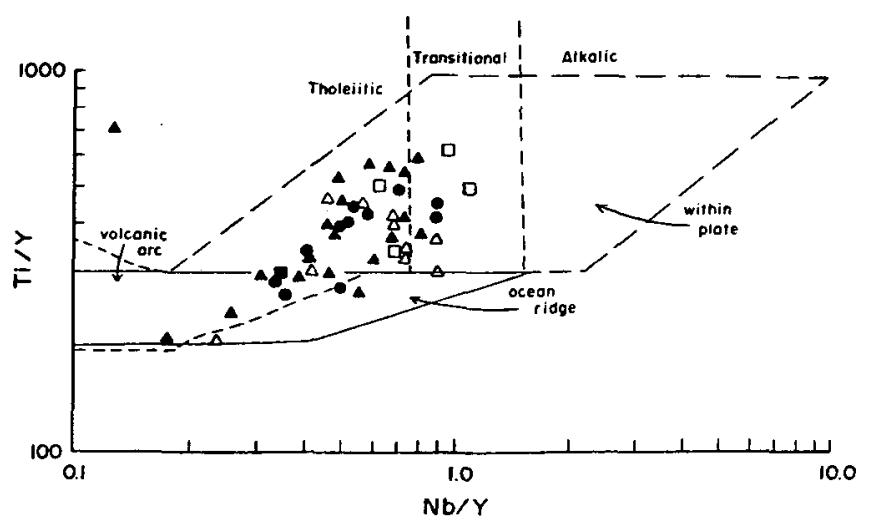

Fig. 11 - Plot of $\mathrm{Ti} / \mathrm{Y}$ against $\mathrm{Nb} / \mathrm{Y}$ for mafic sills of the Bear River, NictauxTorbrook, and Wolfville-Kentville areas. Symbols as in Fig. 6. Fields are from Pearce (1982).

If this interpretation is correct, then the apparent absence of volcanic rocks in the Halifax Formation is perhaps surprising, given the abundance of Type I sills. It is possible that volcanic rocks higher in the Halifax Formation have been eroded, as the relationship with the overlying White Rock Formation is apparently disconformable (Smitheringale 1973, Doyle 1979).

In contrast to the Ordovician age suggested for the Type I sills, at least some of the Type II sills are as young as Devonian because they intruded the Lower Devonian Torbrook Formation and were in turn intruded by the Devono-Carboniferous South Mountain batholith. The simplest interpretation is that all of the Type II sills are Devonian, based on their similar field and petrological features.

These age interpretations for the Type I and II sills do not imply any direct relationship to the UpperOrdovician to Lower Silurian volcanic rocks of the White Rock Formation. However, a relationship is suggested by the geographic proximity of the sills to these volcanic rocks (especially in the Nictaux-Torbrook area) - no mafic sills like those of the present study have been observed in the Halifax Formation in the southeastern part of the Meguma Zone (e.g. Hall 1982) where the White 


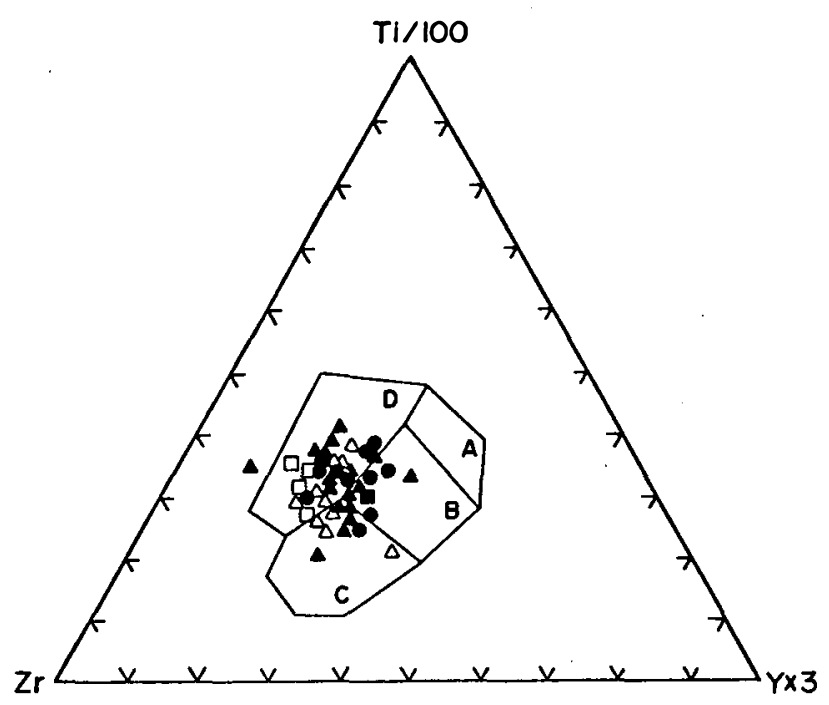

Fig. 12 - Plot of $\mathrm{Ti} / \mathrm{Zr} / \mathrm{Y}$ for mafic sills of the Bear River, Nictaux-Torbrook, and Wolfville-Kentville areas. Symbols as in Fig. 6. Fields $A$ and $B$ (low-potassium tholeiites), B (oceanfloor basalts), B and C (calc-alkalic basalts) and D (within-plate basalts) are from Pearce and Cann (1973)

Rock Formation is absent. Chemical data from the White Rock volcanics in the Yarmouth area (Sarkar 1978) and the Nictaux-Torbrook area ITrapasso 1979, Keppie and Dostal 1980) show that they are transitional between

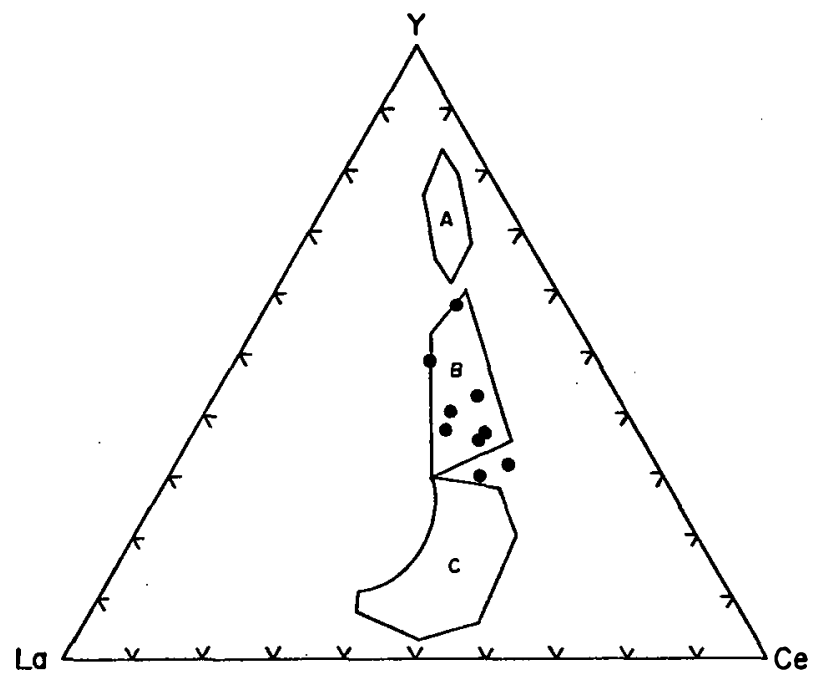

Fig. 13 - Plot of Y-La-Ce for 9 sills from the Nictaux-Torbrook area. Fields A (ocean-floor tholeiltes), B (continental tholeiftes and calc-alkali basalts), and C (alkalic basalts) are from Ricci and Sabatini (1978). tholeiitic and alkalic, and formed in a continental anorogenic environment. Hence they are at least broadly similar to the sills, but this might result from their generation in a tectonic setting which changed little from Ordovician to Early Devonian. The presence of sills in the Torbrook Formation and of highly vesicular sills in the

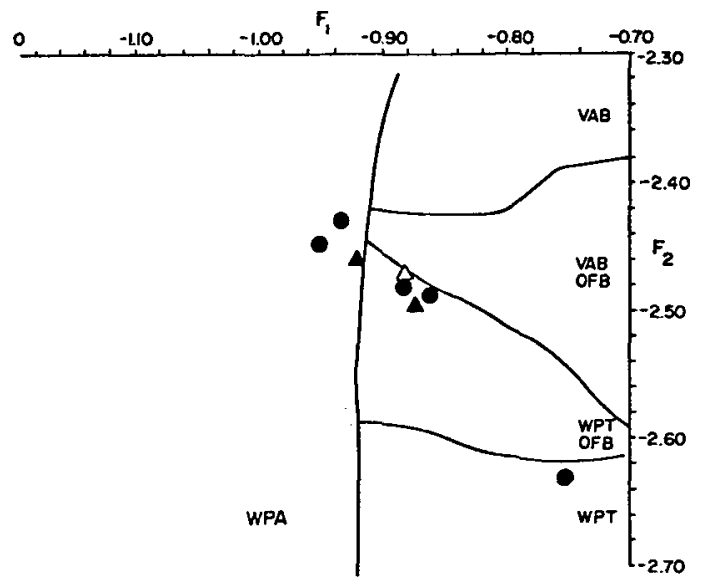

Fig. 14 - Mean clinopyroxene analyses from mafic sills in the Bear River and Nictaux-Torbrook areas plotted on the discriminant diagram of Nisbet and Pearce (1977). Open triangle, Bear River area, Type I; shaded triangle, Bear River area, Type II: circles, Nictaux-Torbrook area, Type II. Data are in Table 2. Fields are volcanic arc basalt (VAB), ocean floor basalt (OFB), within-plate tholeiftic basalt (WPT), and within-plate alkalic basalt (WPA).

Halifax Formation shows that at least those particular sills were not comagmatic with the White Rock volcanic rocks. A more detailed petrochemical study of the volcanic rocks in the Nictaux-Torbrook area (as well as those of apparently similar age in the New Canaan Formation, from which no chemical data are currently available) may resolve the question of their relationship to the sills.

\section{IMPLICATIONS AND CONCLUSIONS}

The chemical data support the interpretation based on field observations and petrography that two types of mafic 
sills are present in the Bear River, Nictaux-Torbrook, and Wolfville-Kentville areas of southwestern Nova Scotia. However, both types are tholeiitic transitional to alkalic and were emplaced in a continental, within-plate tectonic setting.

The ages of the sills have not been definitely resolved. However, on the basis of their restriction to the Halifax Formation and various field and petrographic observations, the Type I sills are interpreted to be older (?Early Ordovician) than the Type II sills, at least some of which are Early to Middle Devonian.

A significant implication of this study concerns the environment of deposition of the Halifax Formation. It has generally been considered to be a deep-sea fan deposit (e.g. Schenk 1971, Harris and Schenk 1976) or to have formed on a submarine plateau (Keppie 1982). However, if it contains approximately contemporaneous sills generated in a within-plate, continental environment, then the Halifax Formation must have been deposited in a deep ensialic basin. Left unanswered is the essential tectonic question of why so many mafic intrusions were emplaced into the rocks of the western Meguma Zone during the Early Palaeozoic.

\section{ACKNOWLEDGEMENTS}

Reviews by J.D. Keppie, G. Pe-Piper, and C.J. Stillman led to major revision and improvement of the original manuscript, and we acknowledge and appreciate their contributions (although the interpretations presented are the responsibility of the authors and not necessarily in agreement with those of the reviewers).

We thank J. Dostal and K. Cameron at St. Mary's University and J. Greenough and D. Press at Memorial University for doing various trace element analyses by XRF for us, and R. Mackay at Dalhousie University for assistance with mineral analyses by microprobe. We are grateful for having been given access to all of these facilities. We also thank C. White who did some of the field studies in the Wolfville and Kentville areas. Graduate studies by Doyle and Trapasso were funded by fellowships and summer stipends awarded by Acadia University. The project was also funded in part by Grant A3320 to S.M. Barr from the Natural Sciences and Engineering Research Council of Canada.

BUCKLEY, E.E. and CRANSTON, R.C. 1971. Atomic absorption analysis of $18 \mathrm{ele}-$ ments from a single decomposition of aluminosilicates. Chemical Geology, 1, pp. 273-284.

CLARKE, B.W. 1977. The geology of the New Canaan Formation, Nova Scotia. B. Sc. (Honours) thesis, Acadia University, Wolfville, 24p.

CROSBY, D.G. 1962. Wolfville map-area, Nova Scotia. Geological Survey of Canada, Memoir 325, 67p.

DOYLE, E.M. 1979. Geology of the Bear River area, Digby and Annapolis Counties, Nova Scotia. M.Sc. thesis, Acadia University, Wolfville, 216p.

FINLOW-BATES, T. and STUMPFL, E.F. 1981. The behaviour of so-called immobile elements in hydrothermally altered rocks associated with volcanogenic submarine-exhalative ore deposits. Mineralium Deposita, 16, pp. 319-328.

FLOYD, P.A. and WINCHESTER, J.A. 1975. Magma type and tectonic setting discrimination using immobile elements. Earth and Planetary Science Letters, 27, pp. 211-218.

HALL, L.R. 1982. Geology of the LaHave River area, Lunenburg County, Nova Scotia. M.Sc. thesis, Acadia University, Wolfville, 161p.

HARRIS, I.M. and SCHENK, P.E. 1976. The Meguma Group (Lower Paleozoic, Nova Scotia). Maritime Sediments, 12 , pp. 25-46.

HUGHES, C.J. 1972. Spilites, keratophyres, and the igneous spectrum. Geological Magazine, 109, pp. 513-527.

KEPPIE, J.D. 1977. Tectonics of southern 
Nova Scotia. Nova Scotia Department of Mines Paper 77-1, 34p.

KEPPIE, J.D. 1979. Geological map of the Province of Nova Scotia. Nova Scotia Department of Mines and Energy, Scale $1: 2,000,000$.

KEPPIE, J.D. 1982. Tectonic map of Nova Scotia. Nova Scotia Department of Mines and Energy. Scale 1:500,000.

KEPPIE, J.D. and DOSTAL, J. 1980. Paleozoic volcanic rocks of Nova Scotia. In "The Caledonides in the U.S.A." Edited by D.R. Wones. Virginia Polytechnic Institute and State University, Department of Geological Sciences. Blacksburg, Virginia, U.S.A. Memoir 2, pp. 249-256.

LANE, T.E. 1976. Stratigraphy of the White Rock Formation. Maritime Sediments, 12, pp. 119-140.

LORING, D.H. 1956. Geology of the White Rock-Black River area, Nova Scotia. M.Sc. thesis. Acadia University, Wolfville, $85 \mathrm{p}$.

NISBET, E.G. and PEARCE, J. A. 1977. Clinopyroxene composition in mafic lavas from different tectonic settings. Contributions to Mineralogy and Petrology, 63, pp. 149-160.

PEARCE, J.A. 1982. Trace isotope characteristics of lavas from destructive plate boundaries. In "Andesites: Orogenic Andesites and Related Rocks", edited by R.S. Thorpe. Wiley-Interscience, pp. 525-548.

PEARCE, J.A. and CANN, J.R. 1973. Tectonic setting of basic volcanic rocks determined using trace element analyses. Earth and Planetary Science Letters, 19, pp. 290-300.

RICCI, C.A. and SABATINI, G. 1978. Petrogenetic affinity and geodynamic significance of metabasic rocks from Sardinia, Corsica and Provence. Neves Jahrbuch Mineralogie Monatshafte, pp. 23-38.

RILEY, R.A. 1964. A part of the Halifax Formation and associated igneous sills, Black River, Kings County, Nova Scotia.
B.Sc. (Honours) thesis, Acadia University, Wolfville, 30p.

SARKAR, P.K. 1978. Petrology and geochemistry of the White Rock metavolcanic suite, Yarmouth, Nova Scotia. Ph.D. thesis, Dalhousie University, Halifax, N.S., 207p.

SCHENK, P. 1971. Southeastern Atlantic Canada, northwestern Africa, and continental drift. Canadian Journal of Earth Sciences, 8, pp. 1218-1251.

SMITHERINGALE, W.G. 1960. Geology of the Nictaux-Torbrook map-area, Annapolis and Kings Counties, Nova Scotia. Geological Survey of Canada, Paper 60-13, 32p.

SMITHERINGALE, W.G. 1973. Geology of parts of Digby, Bridgetown, and Gaspereau map-areas, Nova Scotia. Geological Survey of Canada Memoir 375, $78 \mathrm{p}$.

STILLMAN, C.J. and WILLIAMS, C.T. 1978. Geochemistry and tectonic setting of some upper Ordovician volcanic rocks in east and southeast Ireland. Earth and Planetary Science Letters, 41, pp. 288-310.

TAYLOR, F.C. 1969. Geology of the Annapolis-St. Mary's Bay map-area, Nova Scotia. Geological Survey of Canada Memoir 358, 65p.

TRAPASSO, L. 1979. The geology of the Torbrook Syncline, Kings and Annapolis Counties, Nova Scotia. M.Sc. thesis, Acadia University, Wolfville, $217 p$.

WHITE, C.A. 1978. Petrography and geochemistry of mafic intrusions in the Bear River and Torbrook Syncline areas, Nova Scotia. B.Sc. (Honours) thesis, Acadia University, Wolfville, 107p.

WHITEHEAD, R.E.S. and GOODFELLOW, W.D. 1978. Geochemistry of volcanic rocks from the Tetagouche Group, Bathurst, New Brunswick, Canada. Canadian Journal of Earth Sciences, 15, pp. 207219 .

WILLIAMS, H. 1978. Appalachian Orogen 
in Canada. Canadian Journal of Earth Sciences, 16, pp. 792-807.

WILLIAMS, H, and HATCHER, R.D. Jr. 1982. Suspect terranes and accretionary history of the Appalachian Orogen. Geology, 10, pp. 530-536.

WINCHESTER, J.A. and FLOYD, P.A. 1977. Geochemical discrimination of different magma series and their differentiation products using immobile trace elements. Chemical Geology, 20, pp. 325-343.

Reviewers: J.D. Kepple G. Pe - Piper C.J. St11lman 